\title{
EXPERIMENTAL INVESTIGATIONS OF CONCRETE FILLED BATTENED STEEL COLUMNS OF DIFFERENT SLENDERNESS
}

\begin{abstract}
M. SIENNICKI ${ }^{1}$
The study investigates the axial load behaviour of concrete filled battened steel columns not covered by the design standards. A series of full scale tests on two I-sections connected together with intermediate batten plates and filled with concrete were carried out. The main parameters varied in the tests are length of the members and strength of the concrete filling. One bare steel member was also tested and results were compared with those filled with concrete. The tests results were illustrated by load-strain curves. The main objectives of these tests were twofold: first, to describe behaviour of new steel-concrete columns and second, to analyze the influence of slenderness on load-carrying capacity.
\end{abstract}

Keywords: battened steel column, concrete filled section, experiment, axial strength, behaviour

\section{INTRODUCTION}

In recent years there has been an increase in use of steel-concrete composite columns, mainly due to their high strength, stiffness and fire resistance. However, the existing provisions for design composite compression members included in Eurocode 4 [25] generally apply to only some typical cross-sections, mainly partially or fully encased I-sections or H-sections and concrete-filled tubes. Additionally, shear connectors or reinforcement should be provided in partially or fully encased cross-section [25]. The American standards AISC-LRFD [24] do not exclude the use of provision contained in it, for calculating the load-carrying capacity of steel-concrete columns made of different cross-sections, but provide very general guidelines, difficult to apply without large-scale research.

\footnotetext{
${ }^{1} \mathrm{PhD}$, Eng., Warsaw University of Technology, Faculty of Civil Engineering, ul. Lecha Kaczyńskiego 16, 00-637 Warsaw, Poland, e-mail: m.siennicki@il.pw.edu.pl
} 
There are no common and standard structural design rules for designing columns consisted of two battened steel sections filled with plain concrete. However as it follows from the present engineering practice, such columns could be widely used in construction e.g. in the floor method of underground storey building, in erection buildings with the use of top-down method. Filling with concrete could also be applied for strengthening steel battened columns in existing structures.

The development of multi-storey framed structures inspired Memmler et al. [12] to investigate the behavior of columns consisted of two steel channel sections C140 connected by battens and filled with concrete. Filling with concrete increased the load carrying capacity of axially loaded columns, by $18 \div 77 \%$, depending on the spacing between constituents and strength of concrete. Moreover, the strain readings showed that both steel profiles and concrete core experienced nearly the same deformations and that the concrete deformation ability increased as a result of confinement by steel sections. The steel reached yield strains simultaneously. Klöppel [10] reported that the load carrying capacity of the steel battened channel sections C140 after filling with concrete of $25 \mathrm{MPa}$ cube strength, increased by about $87 \%$. He also noted that the influence of different orientation of flanges (inward or outward) on the strength of columns, is insignificant. Furtheremore, reducing the spacing of battens does not cause any noticeable changes in bearing capacity of the tested columns.

Further recorded research were carried out by Taylor et al. [21]. They tested the behavior of the same type of steel-concrete columns but with battens connected to the edges of flanges by full penetration butt welds. The results of the tests showed composite action between the steel and concrete.

Shakir-Khalil et al. [14,15] conducted a comprehensive analysis regarding the cooperation between steel and concrete in battened steel-concrete columns. It was studied a total of over twenty battened channel sections filled with concrete without shear connectors or steel bars, concentrically and eccentrically loaded up to failure. The starting point was the conclusion drawn by Jones et al. [8] and Stevens [18] who stated that concrete encased steel sections behave like composite elements. The tests carried out by Virdi at al. [23] showed that the resistance to loads pushing the concrete core out of the steel section is ensured due to the surface roughness and geometrical imperfections of the steel cross-section. The results of test carried out by Shakir-Khalil et al. [14,15] showed that the battened steel channel section partially encased in concrete, without shear connectors or steel bars, behaved as one would expect from a typical composite column. However, it was omitted that battens welded to the edges of flanges locally supported the concrete core on their top edges and hence could act as shear connectors. Furthermore, it wasn't explicitly indicated which observed type of failure is decisive for load carrying capacity of the tested columns: crushing of concrete core 
between battens or near to their edges. The load-deflection relationships confirmed the visual observations that the type of failure of the columns indicated no sign of either overall or local instability. Hoffman [5] attempted to determine the load-carrying capacity of the battened channel C120 sections partially encased in concrete of compressive strength $33,9 \mathrm{MPa}$ and observed a strengthening by about $77 \%$.

Hunaiti [6] conducted a series of push-out tests on 139 specimens composed of two battened channels facing each other and filled with plain concrete. It was observed that the bond strength is depended on the type of the cross-section. Battened composite columns offered weaker bond than square and circular concrete-filled tubes.

Discussion on the bond strength in battened composite columns was continued by Srinivasan [16]. On the base of tests conducted on concrete in-filled tubular columns [17] he stated that composite action between steel and concrete depended on the way the load was applied i.e. simultaneously on steel section and concrete.

Hunaiti et al. [7] studied the load-carrying capacity of partially concrete encased single I-section made without any connectors or reinforcement. In one of the tested type of specimens, the ends of the steel-section flanges were connected by battens. The results confirmed that columns behaved like composite members.

Chicoine et al. [1] performed experimental tests on partially encased columns made with built-up shapes. The flanges of steel section were connected by rods welded near to its' toes. It was observed that reinforcement is not needed to reach considerably higher capacity. Moreover, a behavior and failure load were similar in columns subjected to short and long term loads, as it was presented in [2].

Venugopal et al. [22] investigated a failure load of fully encased built-up structural steel sections without reinforcement and then compared with predicted values obtained by using EC4 [25]. The experimental and calculated results showed a very good agreement.

The results of an extensive research program carried-out in natural scale on 23 steel battened columns, made of HE160A sections and partially encased in concrete, were presented in [20,27]. The axial capacity of the columns filled with C20/25 and C50/60 concrete strength class increased by $56 \%$ and $105 \%$, respectively, in comparison with bare steel columns. The growth was higher in columns with smaller battens spacing. The experimental results were confirmed by the finite element analysis. It was observed that the tested steel battened short columns filled with concrete behaved like composite ones. Moreover the experimental strength of the tested columns was very close to the predictions obtained by using EC 4 [25]. 
Montuori et al. [13] tested the influence of battens on concrete confinement in order to strengthen the columns.

Mehrabani et al [11] examined the behavior and ultimate load-carrying capacity of built-up columns fully encased in concrete subjected to axial and eccentric compression. He developed a nonlinear three-dimensional finite element models to simulate the columns. The accuracy of the modeling has been assessed by comparing the results with the corresponding experimental values. The results from the parametric studies showed that the effect of concrete strength is less significant in slender columns with relative slenderness bigger than 1.0. The influence of the yield strength of structural steel is insignificant in specimens of relative slenderness equal or bigger 1.0.

The main objective of the work is to present the experimental study on concrete filled battened steel columns loaded concentrically. The experimental results presented include load-carrying capacity and load-strain behavior with respect to different column length. Another area of consideration is the effect which filling with concrete has on load-carrying capacity. A composite action between the steel and concrete is also considered.

\section{EXPERIMENTAL INVESTIGATION}

\subsection{TEST SPECIMENS PARAMETERS}

In order to consider buckling resistance of concrete filled battened steel columns full scale tests were carried out. Six columns were tested with various length. I-sections IPE80 connected by batten plates were used. Such small steel sections were taken in order to obtain slender specimens under limitation of laboratory conditions. The main characteristics of the columns are listed in Table 1 and their geometry is illustrated in Fig. 1.

Table 1. Technical data of the tested columns

\begin{tabular}{|c|c|c|c|c|c|c|c|c|}
\hline No. & $\begin{array}{l}\text { Column } \\
\text { indication }\end{array}$ & $\begin{array}{l}\text { Type of steel } \\
\text { cross-section }\end{array}$ & $\begin{array}{c}\text { Area of } \\
\text { steel } \\
A_{a} \\
{[\mathrm{~mm} 2]}\end{array}$ & $\begin{array}{c}\text { Battens } \\
\text { spacing } \\
\text { (average) } \\
\text { [mm] }\end{array}$ & $\begin{array}{c}\text { Filling with } \\
\text { concrete }\end{array}$ & $\begin{array}{c}\text { Area of } \\
\text { concrete } \\
\mathrm{A}_{\mathrm{c}} \\
{[\mathrm{mm} 2]}\end{array}$ & $\begin{array}{c}\text { Steel } \\
\text { contribution } \\
\text { ratio } \\
\delta^{*}\end{array}$ & $\begin{array}{l}\text { Length } \\
{[\mathrm{mm}]}\end{array}$ \\
\hline 1 & S1 & \multirow[t]{2}{*}{$2 \times$ IPE 80} & \multirow[t]{2}{*}{1530} & 610 & bare steel & 0 & 1 & 2000 \\
\hline 2 & S1Be0 & & & 610 & filled & 8800 & 0,68 & 2000 \\
\hline
\end{tabular}




\begin{tabular}{|c|c|c|c|c|c|}
\hline 3 & S2Be0-1 & \multirow{2}{*}{450} & filled & \multirow{4}{*}{0,60} & \multirow{2}{*}{1500} \\
\hline 4 & S2Be0-2 & & filled & & \\
\hline 5 & S3Be0-1 & \multirow{2}{*}{570} & filled & & \multirow{2}{*}{3000} \\
\hline 6 & S3Be0-2 & & filled & & \\
\hline
\end{tabular}

$*-\delta=\mathrm{A}_{\mathrm{a}}{ }^{*} \mathrm{f}_{\mathrm{y}} / \mathrm{N}_{\mathrm{pl}}$ (where $\mathrm{f}_{\mathrm{y}}$ given in Table $3, \mathrm{~N}_{\mathrm{pl}}$ acc. to (1))

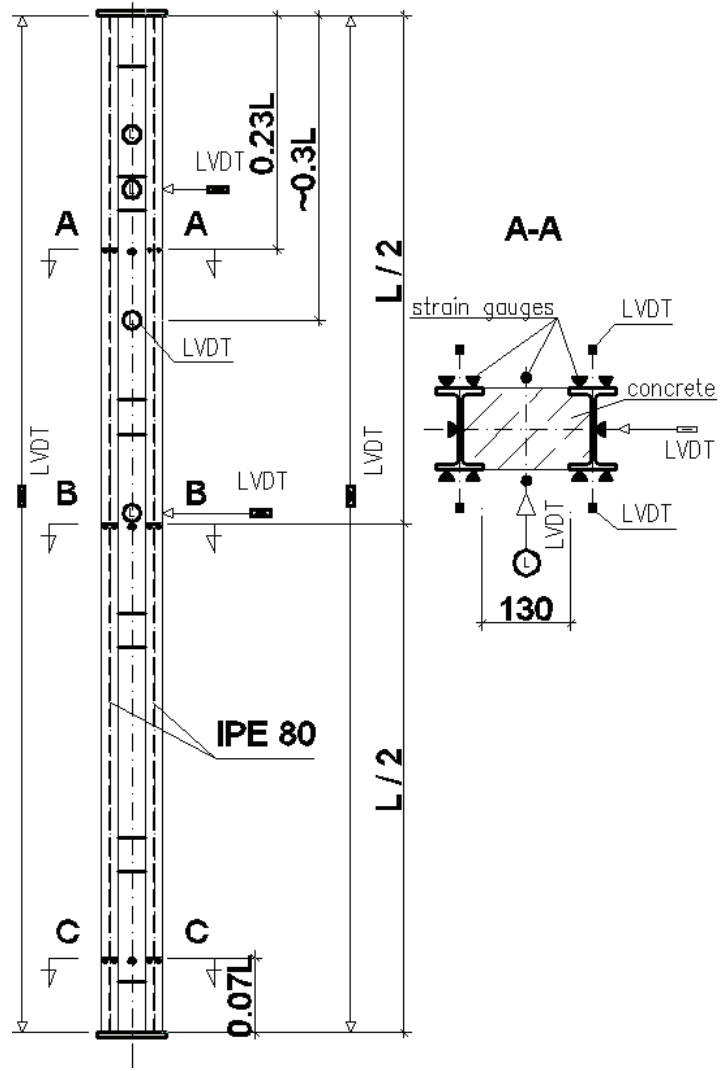

Fig. 1. Type of the tested columns, listed in Table 1, and details of the measurement arrangement

Specimens were composed of two I-sections IPE80 with the length of $1500 \mathrm{~mm}, 2000 \mathrm{~mm}$ and $3000 \mathrm{~mm}$, connected by batten plates. Dimensions of profiles were such as to vary slenderness for flexural buckling mode about minor axis. The spacing of steel chords was chosen such as to provide minimum $80 \mathrm{~mm}$ distance between the toes of steel-section flanges, from the technological point of 
view. The minor axis was perpendicular to the webs of sections. Battens were applied and positioned in accordance with the following assumptions and conditions:

- the column was to be divided into not less than three bays,

- the intermediate battens were to be positioned opposite each other and were spaced and proportioned uniformly throughout the length of the members,

- the battens were to be welded to the flanges of I-sections for their full length

- the thickness of the battens were to be equal the thickness of the flanges of the I-section at the toes.

Five columns were filled with concrete (see Fig. 1), while one column, which was to be used as a reference column, was tested unfilled. Rigid end plates were welded to the specimens ends to distribute the applied load uniformly over the concrete and the steel section. They were used also in order to ensure that premature failure would not occur as a result of local failure at the columns ends.

\subsection{Materials}

Standard cube tests were used to determine the compressive strength for the concrete in accordance to the European Standard [26]. The tests of concrete properties were carried out at the age of 28 days for quality control and during loading tests on the columns. The tested material properties are shown in Table 2 . The modulus of elasticity refers to tests conducted on cylinders (Ø150x300).

Table 2. Test results of concrete

\begin{tabular}{|c|c|c|c|c|c|c|}
\hline No & $\begin{array}{l}\text { Column } \\
\text { indication }\end{array}$ & $\begin{array}{c}\text { Compressive } \\
\text { strength } \\
\mathrm{f}_{\mathrm{cm}} \\
{[\mathrm{MPa}]}\end{array}$ & $\begin{array}{c}\text { Tensile } \\
\text { strength } \\
\mathrm{f}_{\mathrm{ctm}} \\
{[\mathrm{MPa}]}\end{array}$ & $\begin{array}{c}\text { Modulus of } \\
\text { elasticity } \\
\mathrm{E}_{\mathrm{cm}} \\
{\left[\mathrm{MPa} \times 10^{3}\right]}\end{array}$ & $\begin{array}{l}\text { Compressive } \\
\text { strain } \\
\varepsilon_{\mathrm{c}} \\
{[\% \text { o }]}\end{array}$ & $\begin{array}{c}\text { Ultimate } \\
\text { compressive } \\
\text { strain } \\
\varepsilon_{\mathrm{cu}} \\
{[\% \text { o }]}\end{array}$ \\
\hline 1 & S1Be0 & 36,2 & 2,8 & 30,8 & $2,1^{*}$ & $3,5^{*}$ \\
\hline 2 & $\mathrm{~S} 2 \mathrm{Be} 0-1$ & \multirow{4}{*}{51,7} & \multirow{4}{*}{3,7} & \multirow{4}{*}{34,3} & \multirow{4}{*}{1,8} & \multirow{4}{*}{$3,5^{*}$} \\
\hline 3 & S2Be0-2 & & & & & \\
\hline 4 & S3Be0-1 & & & & & \\
\hline 5 & S3Be0-2 & & & & & \\
\hline
\end{tabular}


In order to determine the strength of the steel sections, tensile tests were carried out for sets of coupon samples extracted from webs and flanges of sections. The average properties of tensile tests are given in Table 3.

Table 3. Test results of steel coupons

\begin{tabular}{|c|c|c|c|c|c|c|}
\hline No. & $\begin{array}{l}\text { Column } \\
\text { indication }\end{array}$ & $\begin{array}{c}\text { Yield } \\
\text { strength } \\
\mathrm{f}_{\mathrm{y}} \\
{[\mathrm{MPa}]}\end{array}$ & $\begin{array}{c}\text { Tensile } \\
\text { strength } \\
\mathrm{f}_{\mathrm{u}} \\
{[\mathrm{MPa}]}\end{array}$ & $\begin{array}{c}\text { Modulus of } \\
\text { elasticity } \\
E \\
{\left[\mathrm{MPa} \times 10^{3}\right]}\end{array}$ & $\begin{array}{c}\text { Yield strain } \\
\varepsilon_{y} \\
{[\% o]}\end{array}$ & $\begin{array}{c}\text { Ultimate } \\
\text { strain } \\
\varepsilon_{\mathrm{u}} \\
{[\% \circ]}\end{array}$ \\
\hline 1 & S1 & \multirow{6}{*}{372} & \multirow{6}{*}{491} & \multirow{6}{*}{202} & \multirow{6}{*}{1,8} & \multirow{6}{*}{19,9} \\
\hline 2 & $\mathrm{~S} 1 \mathrm{Be} 0$ & & & & & \\
\hline 3 & $\mathrm{~S} 2 \mathrm{Be} 0-1$ & & & & & \\
\hline 4 & $\mathrm{~S} 2 \mathrm{Be} 0-2$ & & & & & \\
\hline 5 & S3Be0-1 & & & & & \\
\hline 6 & S3Be0-2 & & & & & \\
\hline
\end{tabular}

\subsection{INSTRUMENTATION}

Fig. 1 shows a schematic view of the test arrangement. A total of 42 strain gauges for each specimen were positioned in three levels: top, mid-height and bottom. 30 gauges were placed on flanges and web of the steel cross-section and 12 on the concrete to measure longitudinal and transverse strains.

\subsection{EXPERIMENTAL PROCEDURE}

All specimens were cast in a vertical position. The top surface of concrete was leveled out top of steel sections. Then a cap plate was welded. This was carried out to ensure simultaneous loading steel and concrete. All tests were performed on a $6000 \mathrm{kN}$ capacity testing machine. The specimens were freely placed on the rigid base plate without connecting and were centered in the testing machine to ensure that the compressive axial load was applied without any eccentricity. The tests 
specimens were allowed to rotate multidirectionally by the hinge at the top end of the machine. The end conditions simulated pin-end at the top of the column and flat-end at the bottom to simulate fixed-end conditions. The bottom support condition allowed for some rotation, like in practice where the full rigidity of a fixed built-in ends is never achieved due to the flexibility of the connection or the support. Actually strain readings showed no tension in the bottom part of the specimens thus fixed-end conditions were provided. A typical test setup is presented in Fig. 2.

a)
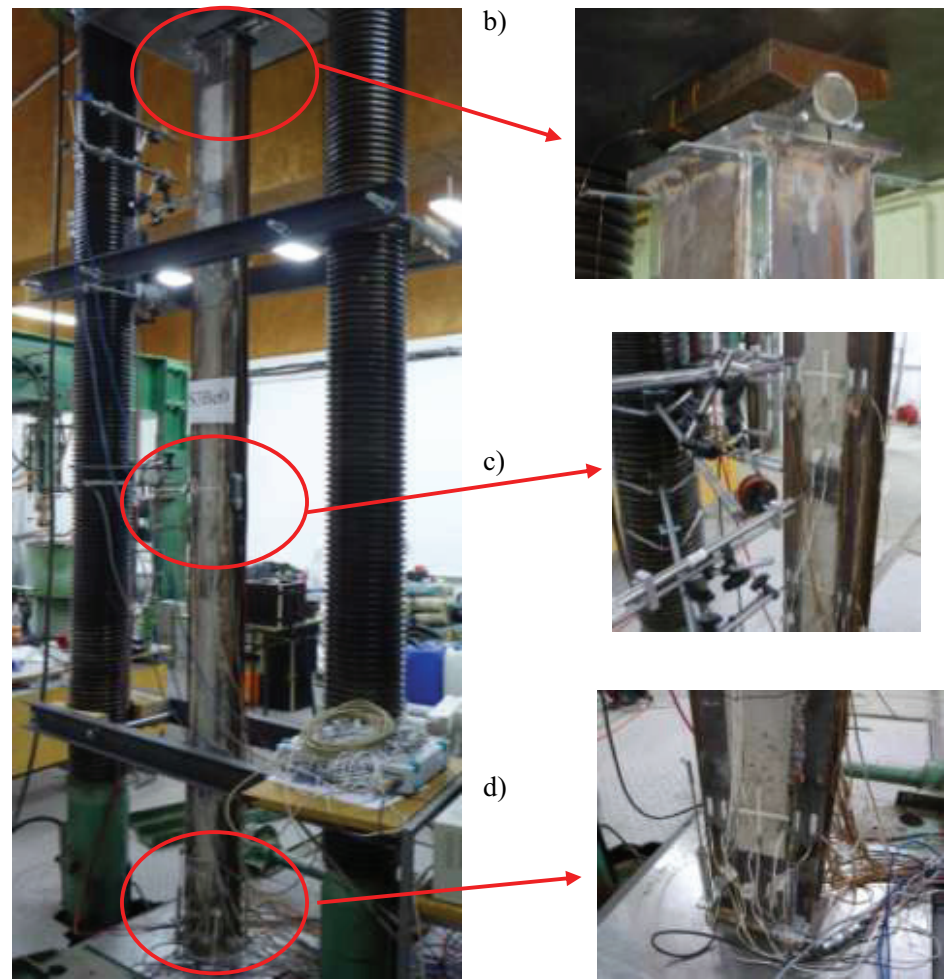

Fig. 2. Test setup: (a) a typical general view; (b) top end; (c) middle; (d) bottom end

Axial load was applied on the columns by roller bearing. A load interval of less than 0.1 of the estimated load capacity was used. The applied load interval was maintained for about two to three minutes. All specimens were loaded up to failure. After the maximum recorded compressive force had been reached, the loading was maintained in order to observe a failure mode and post-peak behaviour. In some cases the maximum value of the load was reached during the last increment. This value was recorded as failure load, after which the immediate drop of the load was observed, due to the column buckling and concrete crushing. 


\section{EXPERIMENTAL RESULTS AND DISCUSSION}

\subsection{General}

Table 4 summarizes the main results obtained for each column.

Table 4. A summary of experimental results for tests specimens

\begin{tabular}{|c|c|c|c|c|c|c|c|}
\hline No & $\begin{array}{l}\text { Column } \\
\text { indication }\end{array}$ & $\begin{array}{c}\text { Exp. } \\
\text { ultimate } \\
\text { strength } \\
\mathrm{N}_{\mathrm{u}}[\mathrm{kN}]\end{array}$ & $\begin{array}{c}\text { Exp. } \\
\text { mean } \\
\text { ultimate } \\
\text { strength } \\
\mathrm{N}_{\mathrm{um}}[\mathrm{kN}]\end{array}$ & \begin{tabular}{|c} 
Strength \\
increamen \\
t due to \\
concrete \\
filling \\
$\mathrm{N}_{\mathrm{u}} / \mathrm{N}_{\mathrm{u} . \mathrm{S} 1}$
\end{tabular} & $\begin{array}{l}\text { Plastic } \\
\text { resistance } \\
\text { of the } \\
\text { cross- } \\
\text { section } \mathrm{N}_{\mathrm{p}} \\
{[\mathrm{kN}]}\end{array}$ & $\begin{array}{l}\text { Reduction } \\
\text { factor } \\
\chi=N_{u} / N_{p l}\end{array}$ & $\begin{array}{c}\text { Mean } \\
\text { reduction } \\
\text { factor } \\
\chi_{\mathrm{m}}=\mathrm{N}_{\mathrm{um}} / \mathrm{N}_{\mathrm{p}}\end{array}$ \\
\hline 1 & S1 & 370 & 370 & - & 568 & 0,651 & 0,651 \\
\hline 2 & $\mathrm{~S} 1 \mathrm{Be} 0$ & 780 & 780 & 2,11 & 839 & 0,930 & 0,930 \\
\hline 3 & $\mathrm{~S} 2 \mathrm{Be} 0-1$ & 950 & \multirow[t]{2}{*}{925} & \multirow[t]{2}{*}{ - } & \multirow[t]{2}{*}{954} & 0,996 & \multirow[t]{2}{*}{0,970} \\
\hline 4 & $\mathrm{~S} 2 \mathrm{Be} 0-2$ & 900 & & & & 0,943 & \\
\hline 5 & S3Be0-1 & 842 & \multirow{2}{*}{809} & \multirow{2}{*}{ - } & \multirow{2}{*}{954} & 0,883 & \multirow{2}{*}{0,848} \\
\hline 6 & S3Be0-2 & 775 & & & & 0,812 & \\
\hline
\end{tabular}

In order to reduce the influence of variation in concrete and steel strength and cross-sectional area, when comparing tests results for different columns, the values of loads were expressed as a load ratio $N / N_{p l}$ of the applied load $N$ to the plastic resistance of the steel-concrete section to compressive normal force $N_{p l}$ given in Eurocode 4 [25] for composite cross-sections, as:

$$
N_{p l}=A_{a} f_{y d}+\alpha A_{c} f_{c d}
$$

where: the coefficient $\alpha$ taken as equal 0.85 , like for the partially concrete encased section; $A_{a}, A_{c}$ are the cross-sectional area of the structural steel section and concrete, respectively. The design values of the compressive strength of concrete $f_{c d}$ and the yield strength of steel $f_{y d}$, were replaced by mean measured values $f_{c m}$ and $f_{y}$, respectively.

It can be seen from results presented in Table 4 that owing to the concrete contribution in carrying axial load, the strength increase for column $\mathrm{S} 1 \mathrm{Be} 0$ is $111 \%$. The expected reducing of the load 
carrying capacity due to column's slenderness is confirmed by the results of reduction factor $\chi$. What is noticeable is that $\chi$ does not seem to be greatly affected by the length in the concrete filled columns compared with bare steel ones. In column S1Be0 with the length of $2000 \mathrm{~mm}, \chi$ is bigger by about $43 \%$ than in bare steel column $\mathrm{S} 1$.

\subsection{FAILURE MODES}

Three main failure modes were observed in the tests:

(I) - concrete spalling on both faces at the top part of the column - vertical and skew cracks from the top to the second batten (Fig. 3) - developed into concrete crushing - in specimens S1Be0 with the length of $2000 \mathrm{~mm}$;

(II) - concrete spalling on the more compressed side of the column, right above the second batten from the top (Fig. 4), developed into concrete crushing and vertical and horizontal cracks between the top and the second batten on the less compressed side, in specimens $\mathrm{S} 2 \mathrm{Be} 0$ with the length of $1500 \mathrm{~mm}$;

(III) - concrete crushing on one face near the middle of the column and horizontal single crack on the opposite side accompanying by the pushing concrete out of steel sections; overall buckling about axis perpendicular to the webs of the steel sections (Fig. 5) in specimens $\mathrm{S} 3 \mathrm{Be} 0$ with the length of $3000 \mathrm{~mm}$;

a)

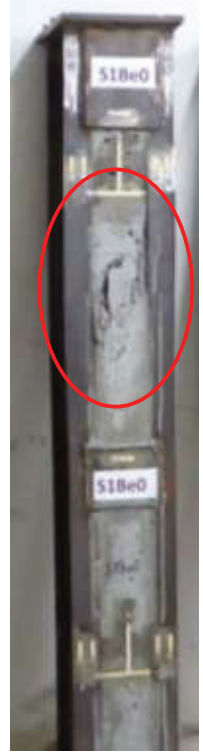

b)

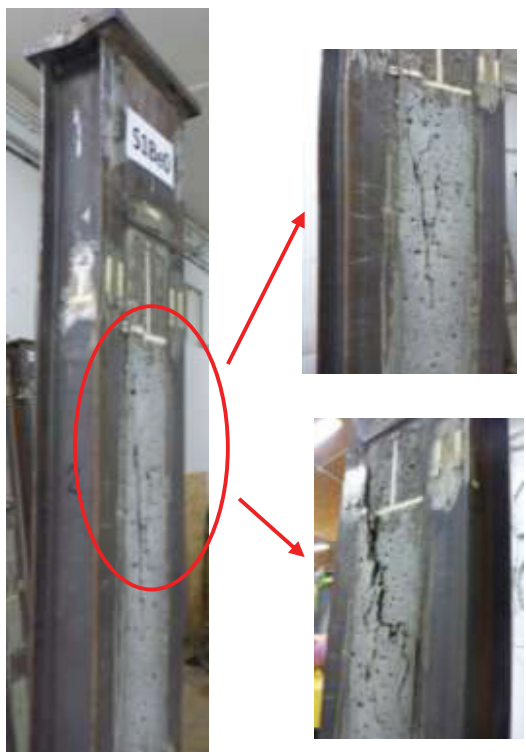

Fig. 3. Example of failure mode (I) for test specimen S1Be0: (a) crushed concrete on the more compressed side; (b) crushed concrete on the less compressed side 
a)

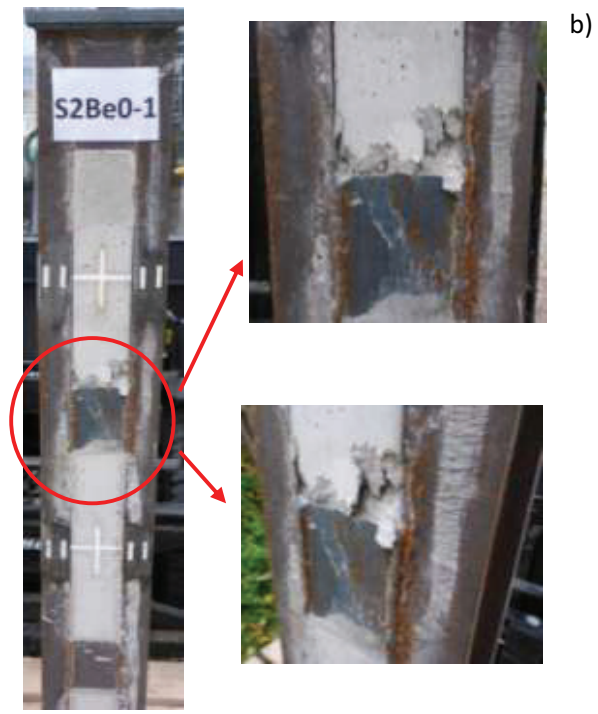

b)

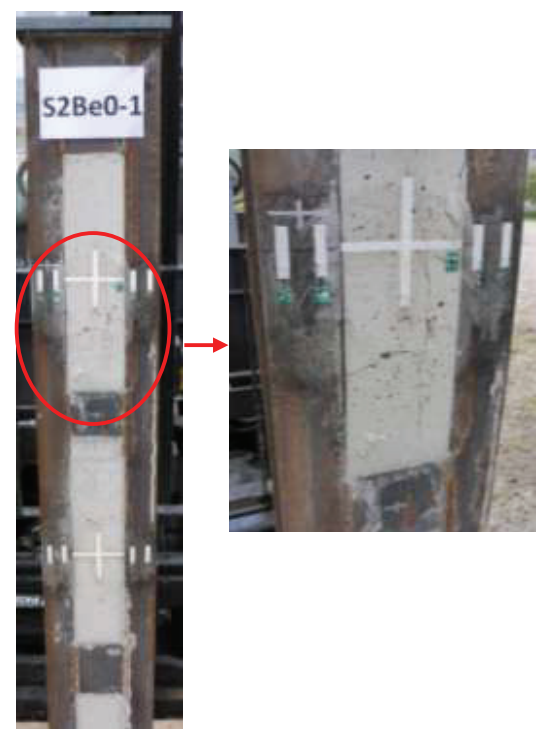

Fig. 4. Example of failure mode (II) for test specimens S2Be0: (a) crushed concrete on the more compressed side; (b) cracking on the less compressed side

a)

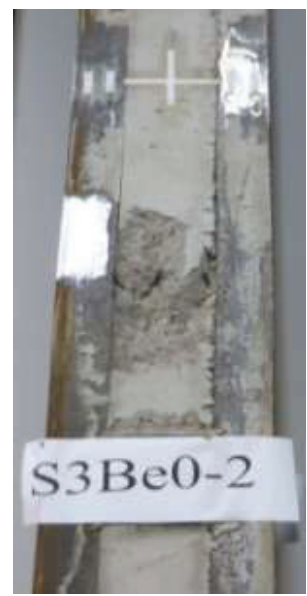

b)

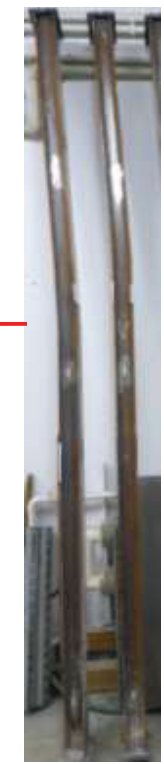

c)

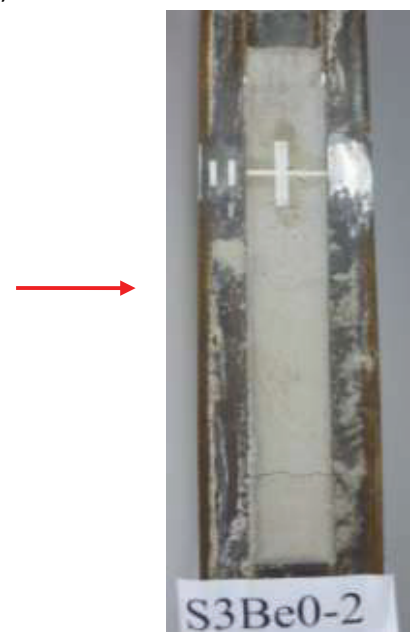

Fig. 5. Example of failure mode (III) for test specimens S3Be0: (a) crushed concrete on the more compressed side; (b) overall buckling mode; (c) horizontal crack on the less compressed side 
The tests clearly showed that failure mode strictly depends on the length and the cross section characteristics of the columns. However it was observed that in all cases the concrete surface spalling occurred normally only at load in excess to about $80 \%$ of the failure load. The observations were confirmed by the measurements of longitudinal strains on the concrete surfaces at the top A-A section, presented in Figs. $6 \div 7$. At the beginning of spalling, i.e. when the applied load was reaching approximately $0.8 \mathrm{~N}_{\mathrm{u}}$, the onset of strains nonlinear increment took place. The columns exhibited rather slow and steady type of failure, except of the column filled with concrete with $\mathrm{f}_{\mathrm{cm}}=79.5 \mathrm{MPa}$, where concrete cracked in sudden and explosive way. No local buckling of the flanges was observed for any of the columns before the peak load was reached. All tested steelconcrete columns exhibited overall buckling above the mid-height, about axis perpendicular to the webs of the steel sections, as it was observed in the post-peak stage of loading. It should be noted that the bare steel column S1 failed due to the local buckling in branches about axis parallel to the webs of the steel sections.

\subsection{LOAD-STRAIN CURVES}

Strains measured at the top section A-A or B-B for $\mathrm{S} 3 \mathrm{Be} 0$ (see Fig. 1), where the biggest values were observed, were taken for comparison. It should be noted that the assumed level of the top section A-A was very close to the most strained one, where failure of columns was observed. In order to estimate an interaction between steel and concrete, recordings from two strain gauges located on steel sections' flanges, adjacent to concrete, were taken into consideration. Moreover, strain readings recorded at those selected gauges indicated the biggest values.

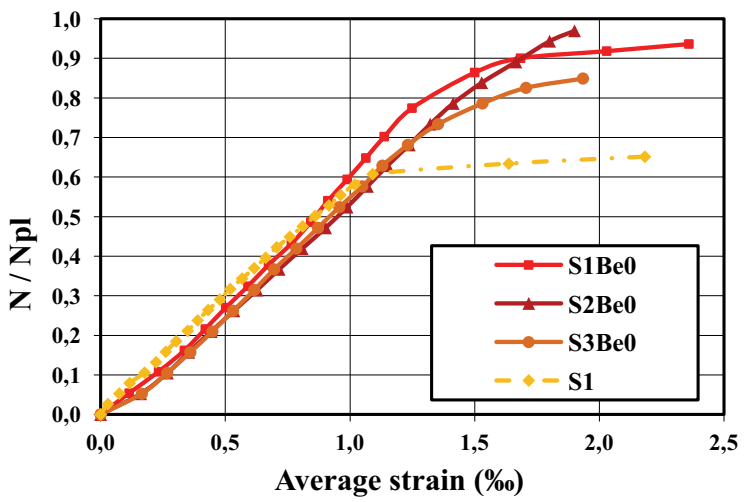

Fig. 6. Experimental N/N $\mathrm{N}_{\mathrm{pl}}$ load ratio versus strain in steel cross section 
Fig. 6 shows the tested curves of $N / N_{p l}$ load ratio versus strains $\varepsilon$ in steel structural cross-section for all type of columns listed in Table 1 . Average values of strains for each type of columns are presented.

Generally, the $N / N_{p l}-\varepsilon$ curves of all specimens closely approach an elastic-plastic behaviour. It can be shown that columns reached its strength at the onset of yield in the steel section, suggesting global buckling failure. Moreover, the specimens exhibited maximum $N / N_{p l}$ values smaller than 1 , as listed in Table 4, indicate that the global effect needs to be taken into account. Hence, it follows that tested specimens may be designed without consideration of local buckling. The steel parts of their cross sections satisfy the limits defined in Eurocode 4 [25]. For the tested specimens the width-to-thickness ratio $b / t_{f}$ is smaller than $44^{*} \varepsilon$, where: $b$ and $t_{f}$ are width and thickness of a flange of the structural steel section, respectively; $\varepsilon=\sqrt{235 / f_{y}}$.

The load ratio $N / N_{p l}-\varepsilon$ curves presented in Figs. 7 provide the information on the redistribution of strains of concrete and steel section.

a)

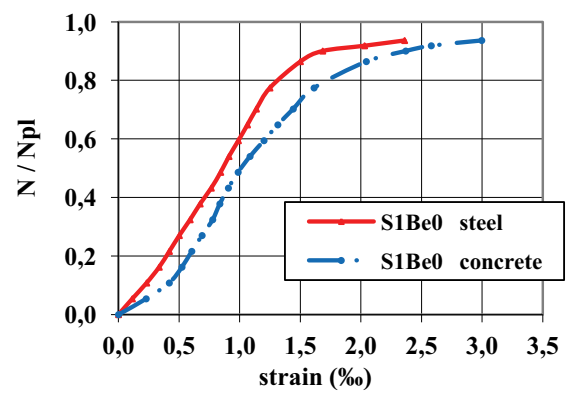

b)

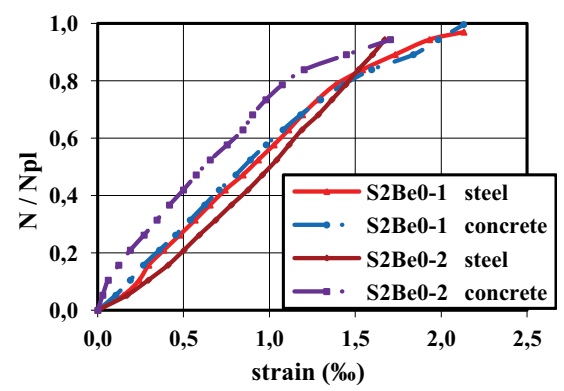

c)

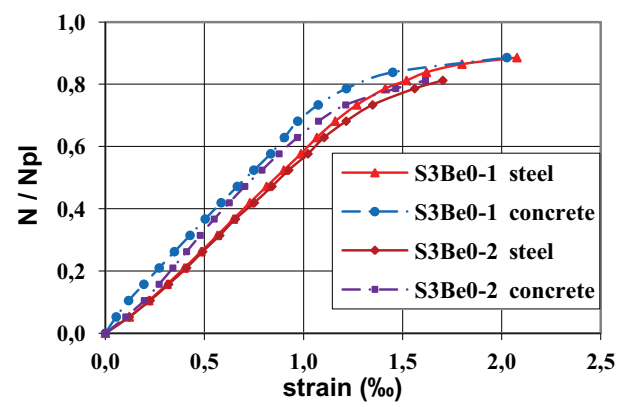

Fig. 7. Experimental $\mathrm{N} / \mathrm{N}_{\mathrm{pl}}$ load ratio versus strain in steel and concrete for columns: (a) $\mathrm{S} 1 \mathrm{Be} 0$; (b) $\mathrm{S} 2 \mathrm{Be} 0$; (c) $\mathrm{S} 3 \mathrm{Be} 0$ 


\section{CONCLUSIONS}

The behaviour of concrete filled battened steel columns under concentric load was investigated experimentally. The tests focused on cases with long columns (slender), with different length and concrete strength.

Based on the presented experimental results, the following conclusions may be drawn:

1) Filling the steel battened columns with concrete, even without the use of shear connectors or reinforcement, revealed that strength and overall stability were enhanced by the steel and concrete interaction. The load carrying capacity increased in long column, composed of two IPE80 section with the length of $2000 \mathrm{~mm}$, by over twice.

2) From the observation of these tests and taking into account the results of studies carried out on low slenderness columns $[20,27]$ it can be conclude that reaching the failure load in steel battened columns with concrete is accompanied by crack spalling between batten plates. Columns fail due to combination of the local and overall buckling associated with concrete crushing. All columns fail in a gradual manner with increasing rate of deflections.

3) Despite the absence of shear connectors or reinforcement composite action between the steel and concrete was observed.

4) In long columns the concrete core exhibited grater compressive strains than strains at the peak stress, due to the confinement of steel section. It may be concluded that in order to calculate the plastic resistance for some considered sections, according to Eurocode 4 [25], the reduction of the concrete strength expressed by coefficient $\alpha=0.85$ could be replaced by $\alpha>0.85$. This complicated and complex phenomenon will be the subject of further research.

5) The proposed new type of concrete filled battened steel column is a possible new form of practical and viable construction worthy of further research. It could be widely used in construction or in foundation work to strengthen the subsoil.

The results presented above are the part of wide range research on the steel battened columns filled with concrete. The objective of the investigations is to establish the strength and behaviour of the short and long columns in concentric and eccentric compression. This new type of section may be broadly used in a top-down construction method, in the floor method of underground storey building. 


\section{REFERENCES}

1. T. Chicoine, R. Tremblay, B. Massicotte, J.M. Ricles, L-W Lu, "Behavior and strength of partially encased composite columns with built-up shapes", Journal of Structural Engineering, March, pp 279-288, 2002.

2. T. Chicoine, R. Tremblay, B. Massicotte, "Long term behavior and strength of partially encased composite columns made with built-up steel shapes", Journal of Structural Engineering, February, pp 141-150, 2003.

3. O. Faber, "More rational design of cased stanchions", The Structural Engineer 34: 88-109, 1956.

4. A. Fam, F. Qie, S. Rizkalla, "Concrete-filled steel tubes subjected to axial compression and lateral cyclic Loads", J.Struct. Eng. ASCE 130: 631-640, 2004

5. P. Hofmann, Tragfahigkeit zweiteiliger Stahlstutzen mit betonfullung, Composite structures, 1 st Scientific Conference, Zielona Góra, Poland, pp 49-55, 1986.

6. Y.M. Hunaiti, "Bond strength in battened composite columns", Journal of Structural Engineering, vol. 117, No.3: 699-714, 1991.

7. Y.M. Hunaiti, B.A. Fattah, "Design consideration of partially encased composite columns", Proceeding Institutional Civil Engineers Structures and Buildings, February, pp 75-82, 1994.

8. R. Jones, A.A. Rizk, "An investigation on the behavior of encased steel columns under load", The Structural Engineer, 41, January, pp 21-33, 1963.

9. A.E. Kilpatrick, B.V. Rangan, "Influence of interfacial shear transfer on behavior of concrete-filled steel tubular columns”, ACI Struct. J. 96: 642-648, 1999.

10. K. Klöppel, „Berechnungsvorschlag für Stahlstützen mit Betonkern auf der Grundlage experimenteller Untersuchungen“, Zentralblatt der Bauverwaltung 55: 536-541, 1935.

11. R. Mehrabani, N.E. Shanmugam, "Finite element analysis of the behaviour and ultimate strength of battened columns encased in concrete", The IES Journal Part A: Civil \& Structural Engineering Vol.7, No. 4: 263-280, 2014, Taylor \& Francis, http://dx.doi.org/10.1080/19373260.2014. 950183.

12. K. Memmler, G. Bierett, G. Grüning, ,Tragfähigkeit von Stahlstützen mit Betonkern bei verschiedenen Betoneigenschaften Und bei auBermittigen Druck“, Der Stahlbau, Beilage zur Zeitschrift, Die Bautechnik, Heft 7, Berlin, pp 49-53, 1934.

13. R. Montuori, V. Piluso, "Reinforced concrete columns strengthened with angels and battens subjected to eccentric load", Engineering Structures 31: 539-550, 2009.

14. H. Shakir-Khalil, Y.M. Hunaiti, "Behaviour of battened composite columns", Conference of Applied Solid Mechanics, University of Strathclyde, Glasgow, U.K., pp 415-433, 1985.

15. H. Shakir-Khalil, Y.M. Hunaiti, "Battened composite columns", IABSE - ECCC Symposium, Steel in Buildings, Luxembourg, pp 325-333, 1985.

16. C.N. Srinivasan, Discussion of "Bond strength in battened composite columns" by Y.M. Hunaiti [12] Journal of Structural Engineering, 117 (3): 1153-1156, 1991.

17. C.N. Srinivasan, "Behaviour of concrete in-filled tubular columns", IABSE - ECCC Symposium, Steel in Buildings, Luxembourg, 1985.

18. R.F. Stevens, "Encased stanchions", The Structural Engineer, 43, February: 59-66, 1965.

19. R.F. Stevens, "Encased stanchions and BS 449", Engineering 188: 376-377, 1956 R.F. Stevens, "Encased stanchions and BS 449", Engineering 188: 376-377, 1956.

20. E. Szmigiera, W. Żółtowski, M. Siennicki, "Research on load capacity of concrete filled columns with battened steel sections", Journal of Civil Engineering and Management 16 (3): 313-319, 2010.

21. R. Taylor, H. Shakir-Khalil, K.M. Yee, "Some tests on a new type of composite column", Proc. Instn. Civ. Engrs, Part 2, 75: 283-296, 1983.

22. R. Venugopal, N. Shanmugan, J.R. Liew, "Built-up columns encased in concrete", Proceedings of the International Conference on Advances in Structures ASSCCA'03, June, pp 759-764, 2003.

23. K.S. Virdi, P.J. Dowling, "Bond strength in concrete filled steel tubes", Proceedings, IABSE, August, pp 125$139,1980$.

24. AISC-LRFD Load and resistance factor design specification for structural steel buildings, American Institution of Steel Construction, Chicago, 1993.

25. EN 1994-1-1, Eurocode 4: Design of composite steel and concrete Structures - Part 1-1: General rules and rules for buildings, 2009.

26. EN 206-1:2000, Concrete - Part 1: Specification, performance, production and conformity, CEN, 2000.

27. M. Siennicki, "The load carrying capacity of axially loaded battened steel columns filled with concrete", Ph.D. Thesis, Warsaw University of Technology, Poland, 2009 [in Polish]. 


\section{LIST OF FIGURES AND TABLES:}

Fig. 1. Type of the tested columns, listed in Table 1, and details of the measurement arrangement Rys. 1. Typy badanych słupów, zestawione w Tabeli 1 oraz detale oprzyrządowania

Fig. 2. Test setup: (a) a typical general view; (b) top end; (c) middle; (d) bottom end Rys. 2. Stanowisko badawcze: (a) typowy widok ogólny; (b) górny koniec; (c) środek; (c) dolny koniec

Fig. 3. Example of failure mode (I) for test specimen $\mathrm{S} 1 \mathrm{Be} 0$ : (a) crushed concrete on the more compressed side; (b) crushed concrete on the less compressed side

Rys. 3. Przykład postaci zniszczenia (I) słupa S1Be0

Fig. 4. Example of failure mode (II) for test specimens S2Be0: (a) crushed concrete on the more compressed side; (b) cracking on the less compressed side

Rys. 4. Przykład postaci zniszczenia (II) słupów S2Be0: (a) zmiażdżony beton na bardziej ściskanej stronie; (b) spękania na mniej ściskanej stronie

Fig. 5. Example of failure mode (III) for test specimens S3Be0: (a) crushed concrete on the more compressed side; (b) overall buckling mode; (c) horizontal crack on the less compressed side

Rys. 5. Przykład postaci zniszczenia (III) słupów S3Be0: (a) zmiażdżony beton na bardziej ściskanej stronie;

(b) ogólna postać wyboczenia; (c) poziome spękania na mniej ściskanej stronie

Fig. 6. Experimental N/N $\mathrm{N}_{\mathrm{pl}}$ load ratio versus strain in steel cross section

Rys. 6. Doświadczalna zależność N/N $\mathrm{N}_{\mathrm{pl}}$ od odkształceń w przekroju stalowym

Fig. 7. Experimental N/Npl load ratio versus strain in steel and concrete for columns: (a) S1Be0; (b) S2Be0; (c) $\mathrm{S} 3 \mathrm{Be} 0$

Rys. 7. Doświadczalna zależność N/Npl od odkształceń stali i betonu w słupach: (a) S1Be0; (b) S2Be0; (c) $\mathrm{S} 3 \mathrm{Be} 0$

Tab. 1. Technical data of the tested columns

Tab. 1. Dane techniczne badanych słupów

Tab. 2. Test results of concrete

Tab. 2. Wyniki badań betonu

Tab. 3. Test results of steel coupons

Tab. 3. Wyniki badań stali

Tab. 4. A summary of experimental results for tests specimens

Tab. 4. Zestawienie wyników badań doświadczalnych słupów 


\section{BADANIA DOŚWIADCZALNE ZLOŻONYCH SŁUPÓW STALOWYCH O RÓŻNEJ SMUKLOŚCI WYPELNIONYCH BETONEM}

Słowa kluczowe: stalowy słup złożony z przewiązkami, przekrój wypełniony betonem, eksperyment, nośność na ściskanie, zachowanie się

\section{STRESZCZENIE:}

W artykule przedstawiono wyniki badań doświadczalnych złożonych słupów stalowych łączonych przewiązkami, wypełnionych betonem. Elementy badawcze poddawane były ściskaniu osiowemu w prasie hydraulicznej, z założonym przyrostem. Parametrami stałymi w badaniach był rodzaj kształtowników stalowych IPE80, rozstaw gałęzi i wielkość przewiązek. Zróżnicowana była długość słupów $1.5 \mathrm{~m}, 2.5 \mathrm{~m}$ oraz $3.0 \mathrm{~m}$ a także klasa betonu wypełniającego. Jeden $\mathrm{z}$ elementów dla celów porównawczych pozostał nie wypełniony betonem. W trakcie badań dokonywano pomiarów odkształceń części stalowej słupa i betonu wypełniającego w wybranych przekrojach, rejestracji skrócenia oraz wygięcia słupów, a także makroskopowej oceny zachowania się elementów pod wpływem rosnącego obciążenia oraz pomiaru maksymalnej siły obciążającej. Zaobserwowano trzy główne postaci zniszczenia słupów, polegające na pękaniu i miażdżeniu betonu, z jednoczesnych lokalnym wyboczeniem profili stalowych w przypadku słupów o długości $1.5 \mathrm{~m}$ i $2.0 \mathrm{~m}$ oraz wyboczeniu globalnym słupów o długości $3.0 \mathrm{~m}$. Dokonano analizy odkształceń stali i betonu, stwierdzając ich współpracę w przenoszeniu obciążenia, analogicznie do słupów zespolonych. Pomierzone wartości odkształceń stali wykazały osiągnięcie granicy plastyczności. Natomiast odkształcenia betonu między przewiązkami przekroczyły wartości odkształceń granicznych odpowiadające maksymalnym naprężeniom. Zatem można wyciągnąć wniosek, że wytrzymałość betonu wzrosła z powodu ograniczenia odkształceń przez profile stalowe. Wydaje się, że w przypadku obliczeń nośności plastycznej przekrojów zbliżonych do badanych, zgodnie z Eurokodem 4, współczynnik redukcyjny wytrzymałości betonu można zwiększyć powyżej wartości 0.85 . Wypełnienie betonem spowodowało wzrost nośności słupa stalowego o długości $2.0 \mathrm{~m}$ o ok. $111 \%$. Stwierdzono także, że w badanych słupach dwugałęziowych wypełnionych betonem, wpływ smukłości ma znacząco mniejszy wpływ na zmniejszenie nośności niż w słupach stalowych - dla elementów o długości $2.0 \mathrm{~m}$ o około $43 \%$.

Uzyskane rezultaty badań potwierdzają praktyczny aspekt stosowania tego typu przekrojów w słupach o dużej nośności oraz przemawiają za prowadzeniem badań w kierunku ustalenia czy można traktować je, a w rezultacie obliczać, jako zespolone.

Received 15.11.2018

Revised 03.10.2019 